\title{
Salinization during salt-marsh restoration after managed realignment
}

\author{
Roos M. Veenklaas ${ }^{1,2} \cdot{\text { Elske C. } \text { Koppenaal }^{1} \text { • Jan P. Bakker }}^{1} \cdot$ Peter Esselink $^{1,3}$
}

Received: 13 December 2014 /Revised: 1 May 2015 /Accepted: 4 May 2015 /Published online: 3 July 2015

(C) The Author(s) 2015. This article is published with open access at Springerlink.com

\begin{abstract}
Salt marshes provide an important and unique habitat for plants and animals. To restore salt marshes, numerous coastal realignment projects have been carried out, but restored marshes often show persistent ecological differences from natural marshes. We evaluate the effects of elevation and marsh topography, which are in turn affected by drainage and livestock grazing, on soil salinity after de-embankment. Salinity in the topsoil was monitored during the first 10 years after de-embankment and compared with salinity in an adjacent reference marsh. Additionally, salinity at greater depths (down to $1.2 \mathrm{~m}$ below the marsh surface) was monitored during the first 4 years by measuring the electrical conductivity of the groundwater. Chloride concentration in the top soil strongly decreased with increasing elevation; however, it was not affected by marsh topography, i.e. distance to creek or breach. Chloride concentrations higher than $2 \mathrm{~g} \mathrm{Cl}^{-}$/litre were found at elevations below $0.6 \mathrm{~m}+$ MHT. Salinization of the groundwater, however, took several years. At low marsh elevations, the salinity of the deep groundwater (at $1.2 \mathrm{~m}$ depth) increased slowly throughout the full 4-year period of monitoring but did not reach the level of seawater. Compared to the ungrazed treatment, the grazed treatment led to lower accretion rates, lower soil-moisture content and higher chloride content of soil
\end{abstract}

Roos M. Veenklaas

r.veeneklaas@bosgroepen.nl

1 Conservation Ecology, Groningen Institute for Evolutionary Life Sciences, University of Groningen, PO Box 11103, 9700 CC Groningen, The Netherlands

2 Bosgroep Noord-Oost Nederland (Forest Support Group), Balkerweg 48a, 7738 PB Witharen, The Netherlands

3 PUCCIMAR Ecological Research and Consultancy, Boermarke 35, 9481 HD Vries, The Netherlands moisture. The de-embankment of the agricultural grasslands resulted in a rapid increase of soil salinity, although deeper ground-water levels showed a much slower response. Elevation accounted for most of the variation in the salinization of the soil. Grazing may enhance salinity of the top soil.

Keywords Drainage $\cdot$ Elevation · Grazing management . Salinity
Abbreviations
EC Electrical conductivity
MHT Mean high tide
NFB Noard-Fryslân Bûtendyks

\section{Introduction}

Coastal salt marshes provide an important and unique habitat for plants and animals. This habitat is restricted to a narrow zone between land and sea and is subjected to extreme environmental conditions due to periodic flooding by seawater and high salinity. As a consequence, salt-marsh plant communities consist of a small number of highly adapted plant species, some of which are considered rare and vulnerable to local extinction (Doody et al. 1993; Westhoff et al. 1993). Loss or degradation of salt marshes is a global phenomenon; approximately $50 \%$ of the salt-marsh area worldwide has been lost (Adam 2002). Over the past centuries, large areas of salt marshes were embanked either for the acquisition of new agricultural land or for coastal defence, harbour and industrial development (Dijkema 1987; Bakker et al. 2002). This process of progressive land claims has become less acceptable for a number of reasons. Firstly, there is growing awareness that 
salt marshes are important habitats that need to be protected and conserved for their nature conservation value. Secondly, an important insight has been gained that salt marshes provide an important ecosystem service in coastal defence as they act as a natural buffer for dissipating wave energy in front of the seawall (Gedan et al. 2011; Möller et al. 2014). Thirdly, embankments for new agricultural land are economically of less interest in Europe (Bakker et al. 1997).

Numerous projects and various approaches to restore salt marshes after embankment have been carried out along the North Sea coast during the past few decades (Wolters et al. 2005). The aims of these projects were a) to restore salt-marsh ecosystems, b) to reduce costs in current coastal defence, or c) to achieve both goals. An increasingly important option is managed coastal re-alignment (French 2006; TEEBcase 2011). Coastal re-alignment (i.e. de-embankment) involves reintroducing tidal inundation to formerly reclaimed land, through the breaching of coastal embankments. Several studies have evaluated the effects of de-embankment on vegetation composition (Wolters et al. 2005; Garbutt and Wolters 2008; Hughes et al. 2009; Mossman et al. 2012a) and environmental characteristics such as inundation frequency and soil redox potential (Pétillon et al. 2010; Davy et al. 2011; Mossman et al. 2012b). However, the process of salinization after de-embankment has rarely been studied.

Elevation within the tidal frame is of primary importance for plant distribution in coastal salt marshes and is the physical basis of the distinctive zonation of halophytic plant species (e.g. Zedler et al. 1999; Bockelmann et al. 2002; Pétillon et al. 2010). The influx of salt into the salt-marsh bed occurs during tidal inundation when soil pore water is refreshed by vertical seepage (Childers et al. 2000). This explains the generally negative relationship between elevation and salinity. However, marsh topography also strongly affects the frequency and duration of water retention (Davy et al. 2011; Veeneklaas 2013). At the meso-scale within a salt marsh, the vegetation pattern may be strongly influenced by fluvial geomorphic processes, such as drainage patterns in relation to tidal creeks (Zedler et al. 1999). Kim et al. (2010) found lower salinity near elevated creek banks due to shorter periods of salt accumulation and higher salinity in depressions due to stagnation and evapotranspiration of seawater after tidal flooding.

The relationship between soil salinity and elevation may not only be affected by marsh topography but also by grazing management. Studies have shown that grazing affects edaphic processes by trampling and reduction of plant cover (e.g. Lavado and Alconada 1994; Srivastava and Jefferies 1996; Schrama et al. 2013). Di Bella et al. (2014) found increased soil salinity at higher elevations due to grazing; however, increased salinity was not found at lower elevations because tidal flooding counterbalanced the increase in evapotranspiration promoted by biomass removal. Surface-elevation increase has been found to be higher in ungrazed than in grazed salt marshes (Suchrow et al. 2012). Furthermore, surface elevation will increase as a result of sediment input after deembankment (Nolte et al. 2013). Increasing elevation may result in lower soil salinity, but this effect may be partly counterbalanced by greater compaction resulting from the trampling by grazing animals.

In order to broaden the knowledge base for salt-marsh restoration in de-embankment projects, it is important to study the processes that may determine salt-marsh development after de-embankment (Wolters et al. 2008). In de-embankment projects, it is important to restore the environmental factors as these factors determine the distribution of plant species and, hence, the vegetation patterns and zonation (Silvestri et al. 2005; Pétillon et al. 2010). In the framework of salt-marsh restoration, a summer polder which had been embanked from a salt marsh was de-embanked in 2001 on the Dutch mainland coast of the Wadden Sea. In order to allow for evaluation of changes in both abiotic and biotic parameters, a monitoring program was developed. This study started the year prior to de-embankment and was implemented for up to 10 years following de-embankment. The monitoring setup allowed us to study the effect of drainage and grazing on salinization during this 10 -year period. We hypothesized that:

i) de-embankment of agricultural grasslands will result in higher soil salinity;

ii) variation in elevation and drainage will account for much of the variation in salinization of the soil;

iii) livestock grazing will result in enhanced soil salinities because (a) biomass removal will enhance evapotranspiration, and (b) trampling will reduce surfaceelevation increase by compaction.

\section{Methods}

\section{Study area and de-embankment site}

The study area is part of Noard-Fryslân Bûtendyks (NFB; $\mathrm{N} 53^{\circ} 20^{\prime}, \mathrm{E} 5^{\circ} 5^{\prime}$ ), the largest remaining continuous track of land outside the main seawall on the Dutch mainland coast of the Wadden Sea. NFB is comprised of high intertidal mud flats and pioneer salt marsh seaward (1600 ha protected by brushwood groynes, 1500 ha artificially developed salt marshes) and about a dozen summer polders landward, which had been embanked between 1892 and 1956 (c. 1000 ha). The de-embanked site is a former summer polder of 117 ha within the study area, which had been embanked in 1909 (Schroor 2009). The de-embanked site is surrounded by an adjacent salt marsh on the seaward side, which was selected as the reference site, and other summer polders on the landward side (Fig. 1). In 2000, the year prior to de-embankment $(t=-1)$, 
Fig. 1 De-embanked site and adjacent reference salt marsh (northwest) showing the three creeks and the sampling stations. The symbols show locations of sampling stations with different treatments. (Aerial photograph Province of Fryslân)

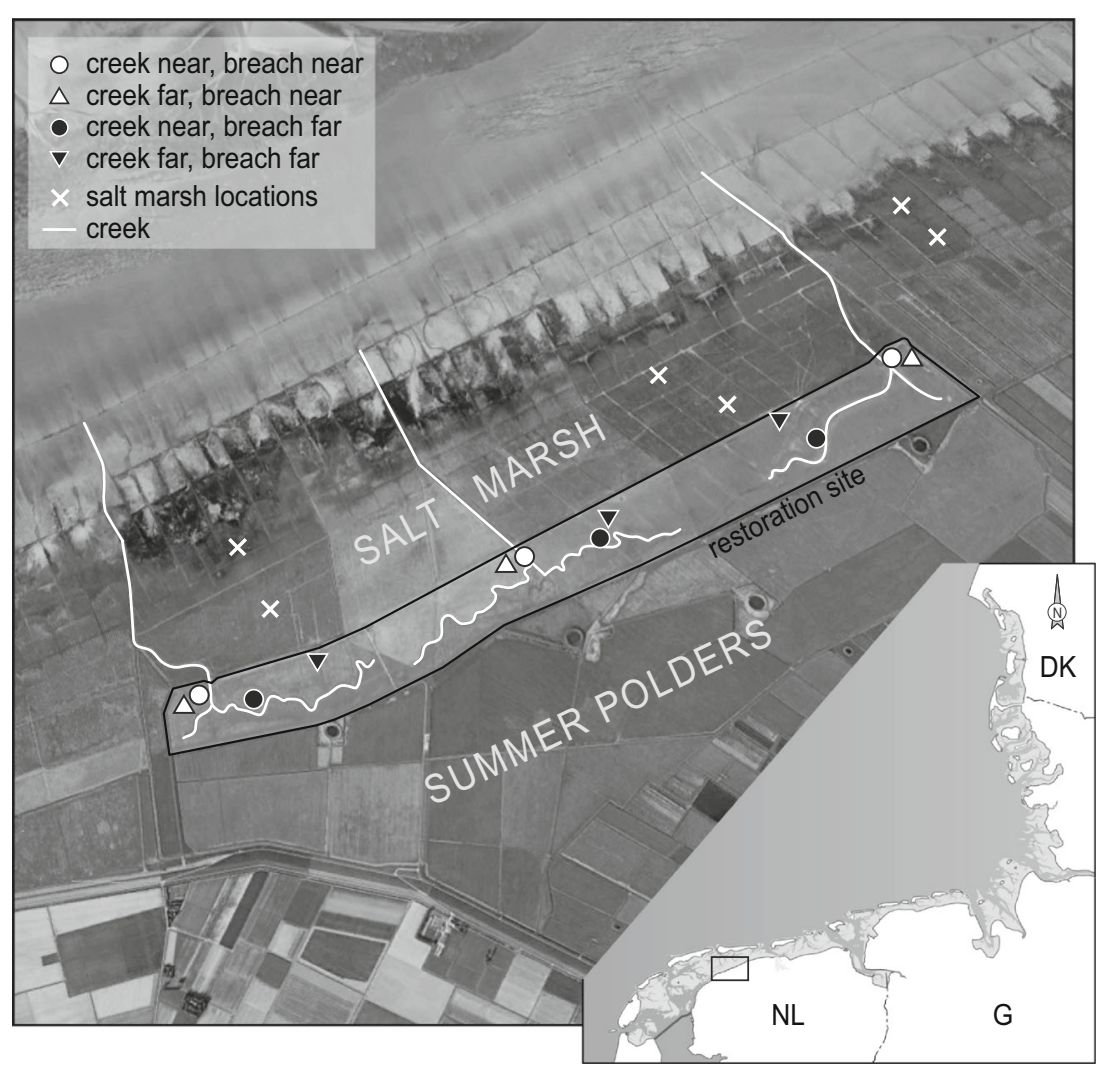

three artificial creeks were excavated for the supply and discharge of seawater and sediment, with an initial width of 5$10 \mathrm{~m}$. This resulted in three catchment areas, each of about 40 ha. In September $2001(t=0)$, breaches of $20-40 \mathrm{~m}$ in width were made in the summer-polder bank at the intersection of these three creeks with the seaward summer-polder bank. The summer polders are grazed by livestock, namely cattle and horses. After de-embankment, livestock grazing was continued at varying stocking densities. From 2008 onwards, however, a clearly higher stocking density of horses was applied in part of the de-embanked site.

The tidal range at the study area is $1.85 \mathrm{~m}$ with an annual mean high tide (MHT) of $1.0 \mathrm{~m}$ above NAP (Dutch Ordnance Level). The elevation of the de-embanked site ranges between $0.3 \mathrm{~m}$ and $0.9 \mathrm{~m}+$ MHT. In the de-embanked site, a higher elevated western part can be distinguished from the lower eastern part with around a $0.2 \mathrm{~m}$ difference in average elevation. High-tide levels for the study area have been calculated from the average level of each high tide at the gauges stationed at Harlingen and Lauwersoog, which are $30 \mathrm{~km}$ west and $30 \mathrm{~km}$ east of the de-embanked site, respectively. Theoretically, the lowest points in the de-embanked site with an elevation of $0.3 \mathrm{~m}+$ MHT were inundated 100 times per year on average during the first 10 years after de-embankment; the highest points at $0.9 \mathrm{~m}+$ MHT were inundated 12 times per year. Tidal inundations occurred mainly from September through March and were relative infrequent during the growing season
(Fig. 2a). The average precipitation is $820 \mathrm{~mm}$ per year (1981-2010 average at Leeuwarden Airfield, $12 \mathrm{~km}$ south of the study site; data from the Royal Netherlands Meteorological Institute).

\section{Experimental set-up}

In order to evaluate the effects of the artificial creeks and breaches on the restoration process, twelve sampling stations were installed in a stratified design within the de-embanked site with four stations per catchment area. In each catchment area, the stations were situated as follows: a) close to both creek and breach, b) close to the creek but far from the breach, c) far from the creek but close to the breach and d) far from both creek and breach (Fig. 1). To evaluate the effect of grazing, an exclosure was installed at each station before the start of the first grazing season after de-embankment. At each sampling station, three $4 \mathrm{~m} \times 4 \mathrm{~m}$ permanent plots were established both inside and outside the exclosure, which resulted in 72 permanent plots in the de-embanked site.

On the grazed salt marsh adjacent to the de-embanked summer polder (reference site), samples were collected in two vegetation zones from three sampling stations per zone. Each station was comprised of three $4 \mathrm{~m} \times 4 \mathrm{~m}$ permanent plots. For practical reasons, no exclosures were erected on the reference salt marsh. In order to compare the de-embanked 

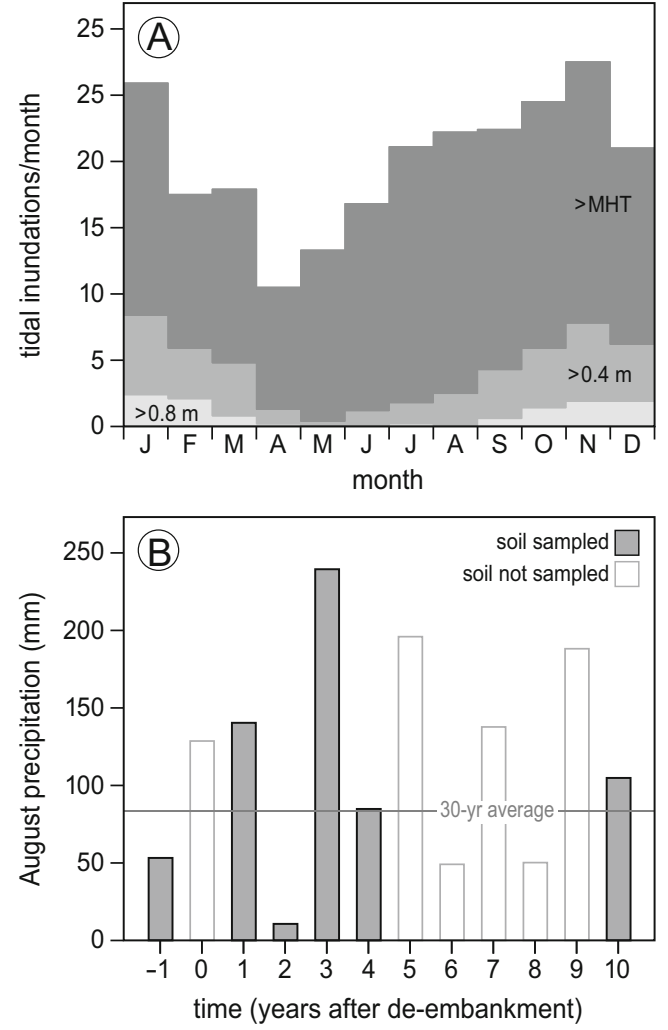

Fig. 2 a Monthly variation in high-tide levels over the study period (2001-2011) in the study area. Mean high tide (MHT) is equal to $1.0 \mathrm{~m}+$ NAP (Dutch Ordnance Level). b Monthly precipitation in August during the study period (2001-2011) for years when soil samples were taken and for unsampled years. Horizontal line represents the average precipitation in August from 1981 to 2010 (data Royal Netherlands Meteorological Institute, station Airfield Leeuwarden)

site with the reference salt marsh, all plots in the study with an initial elevation of lower than $0.50 \mathrm{~m}+$ MHT were assigned to the "low" category, and plots above this level were assigned to the "high" category.

Soil-moisture content and soil salinity were measured at each permanent plot at all sampling stations. Soil salinity was measured for 6 years by collecting soil samples during a single sampling per year at the end of August, namely: 1 year prior to de-embankment, the first 4 years after deembankment and 10 years after de-embankment. Though soil salinity may show a high temporal variation (e.g. de Leeuw et al. 1990), a single sampling may clarify the degree of variation among plots, including the differences between deembanked and reference sites, and grazed and ungrazed treatments. From each permanent plot, 12 subsamples were taken from the top soil $(0-5 \mathrm{~cm})$, mixed and sealed in plastic bags for transport to the laboratory for further processing. Soilmoisture content was measured by the weight lost after drying the soil at $105{ }^{\circ} \mathrm{C}$ for $48 \mathrm{~h}$. Salinity was measured with a chloride-sensitive electrode in water extracts obtained after centrifuging soil suspensions (15 $\mathrm{g}$ fresh soil, $50 \mathrm{ml}$ distilled water; Hofstee 1983). Soil salinity was expressed as the concentration of the chloride ion in soil moisture (gram $\mathrm{Cl}^{-}$ per litre soil moisture). One year prior to de-embankment, three wells were installed at six of the sampling stations (far from the creek) to measure groundwater level and salinity. The wells enabled groundwater composition measurements at depths of 30,60 and $120 \mathrm{~cm}$ below the initial soil surface. For practical reasons, these wells were only maintained up to and including the fourth year after de-embankment. Electrical conductivity (EC) of the groundwater was measured monthly. To measure the actual conductivity, the wells were emptied $24 \mathrm{~h}$ prior to measurement.

Weather conditions prior to soil sampling varied considerably between years (Fig. 2b) and probably affected soilmoisture content and soil salinity. In Fig. 2b, August precipitation is used as a parameter for weather conditions. Weather was exceptionally dry in the second year, and wet to extremely wet in the first and third years after de-embankment. Tidal inundation in August showed less variation between years. High tides in August theoretically did not exceed the level of $0.60 \mathrm{~m}+$ MHT during the first 2 years of soil sampling and only once in each of the other 4 years; the lower level of $0.40 \mathrm{~m}+$ MHT was exceeded 1-5 times in August.

Surface-elevation change was measured next to each permanent plot, where sedimentation-erosion-bars (SEB) were installed. A SEB-point is comprised of two horizontally aligned poles $(7.5 \mathrm{~cm}$ in diameter and $1.5 \mathrm{~m}$ long) spaced $2 \mathrm{~m}$ apart and driven at least $1 \mathrm{~m}$ deep into the marsh bed into the sandy layer underneath the clayey surface deposits (Nolte et al. 2013). The height of the poles was calibrated with respect to Dutch Ordnance Level (NAP) at the start of the monitoring and was recalibrated twice during the following 10 years. During measurements, a $2 \mathrm{~m}$-long aluminium bar with 17 holes was placed on the poles, and surface elevation was measured by lowering a $50-\mathrm{cm}$ long pin through each of the 17 holes down to the marsh surface.

\section{Statistical analyses}

For the comparison between the de-embanked site and the reference salt marsh, statistics were only applied on the data within the grazed sites. A general linear model (GLM) was used to examine the relation between the soil parameters, and the differences between the de-embanked site and the reference site within each year.

To examine the effects of the artificial creeks and breaches within the de-embanked site, statistical analyses were only applied on the data within the grazed de-embanked site. Soil-moisture content and soil salinity were tested separately. A generalized estimation equation (GEE) was used to address the influence of temporal and spatial variables because explorative analysis showed violations of independence and heterogeneity, which were caused by a great number of locations 
with few replicates and a high number of repeated measurements over time. The correlation structure applied was exchangeable since the soil-moisture content and chloride concentration values were not dependent over time. This was supported by comparing differences between naive and robust standard errors (Hardin and Hibe 2003). An ANOVA test was used to identify the adequate model. In the parsimonious model, we used year, sampling station and elevation. The relation between elevation and chloride content of soil moisture per year was estimated with a curve-fit analysis, including a linear and exponential regression model. A GLM was applied to test the significant differences of the regression models between years. A paired $t$-test was performed between data inside and outside the exclosures to test the effect of grazing on surfaceelevation change, soil-moisture content and chloride concentration in soil moisture. In order to avoid pseudo-replication, we used the average value for each sampling station in all statistical analyses, resulting in $N=12$ within the deembanked site and $N=6$ within the reference salt marsh. All data were analysed using SPSS Statistics 22 (IBM SPSS software) and R3.0.2 (Foundation of Statistical Computing).

\section{Results}

\section{Salinization over time after de-embankment}

After the breaches had been created in the summer-polder bank in 2001, both soil-moisture content and chloride concentration in the de-embanked site increased significantly (Table 1, Fig. 3). Large fluctuations between years were observed, however. These annual fluctuations appeared to correspond with amount of rainfall prior to soil sampling (Fig. 2). For example, August of year 2 after de-embankment was extremely dry, and concurrently low soil-moisture contents were observed in both the de-embanked site and the reference salt marsh. In year 1 after de-embankment in both the deembanked site and the reference salt marsh, no significant relation was found between elevation and soil-moisture content (Fig. 4a). In years 2-4 after de-embankment, the soilmoisture content was significantly negatively related with elevation in the de-embanked site and the reference salt marsh. In year 10 after de-embankment, no relation was found between soil-moisture content and elevation in the de-embanked site, but a significant negative relation was found in the reference salt marsh (Fig. 4b).

A significant negative relationship was found between elevation and chloride concentration from the first year onwards after de-embankment. In the first years after de-embankment, a significant difference was observed between the deembanked site and reference salt marsh. Namely, lower chloride concentrations were found in the de-embanked site than in the reference salt marsh at comparable elevations (Fig. 4c, GLM F $=12.542, d f=1, P=0.003)$. Five and 10 years after de-embankment, no significant difference was found between the de-embanked site and the reference salt marsh; thus, no significant difference was found between the elevation and chloride concentration relationships found at the deembanked and reference site (Fig. 4d, GLM F $=1.146, d f=1$, $P=0.301)$.

The salinity in the groundwater gradually increased during the first years after de-embankment before it levelled off. Figure 5 shows the salinization of the groundwater at two sampling stations. The salinization of shallow groundwater $(30 \mathrm{~cm})$ occurred more rapidly at low elevations than at higher elevations in the de-embanked polder. Secondly, at lower elevations, salinity of the deeper groundwater continued to increase until the end of the measurements in year 4. The chlorinity of sea water in this part of the Wadden Sea is on average $16.1 \mathrm{~g} \mathrm{Cl}^{-} / \mathrm{dm}^{3}$ (2009-2011 average based on monthly sampling by Rijkswaterstaat at Dantziggat (N5324.068, E $\left.5^{\circ} 43.619\right)$ ). This chlorinity is equivalent to an $\mathrm{EC}$ value of approximately $45 \mathrm{mS} / \mathrm{cm}$. At high surface elevations in the de-embankment site with low flooding frequencies, the groundwater salinity (EC value) levelled off at a much lower level at all depths (Fig. 5a). At low surface elevations, the salinity of shallow groundwater had already reached a similar level to sea water by 2 years after de-embankment. The salinity of the deep groundwater $(120 \mathrm{~cm})$ increased slowly throughout the full 4-year period of monitoring but did not reach the level of seawater (Fig. 5b).

\section{Effect of marsh topography on salinity within the de-embanked site}

The topography of the de-embanked site, expressed as distance to creek or breach, had a significant influence on the soil-moisture content (Table 1). Locations situated far from a creek had higher soil-moisture content than locations near a creek (Fig. 6a). Overall, soil-moisture content was significantly higher at low elevations (Table 1), though strong variation between years was observed. When years were analysed separately and topography was not taken into account, no significant relation was found between elevation and soil-moisture content (Figs. 4 and 6b). In contrast to soil-moisture content, soil salinity was not significantly affected by marsh topography, expressed as distance to creek and breach (Fig. 6c).

\section{Effect of grazing on salinity within the de-embanked site}

Significantly higher soil-moisture content in the ungrazed plots was observed 3 years after de-embankment. However, 
Table 1 GEE-model output for two salinity parameters: soilmoisture content and chloride concentration of soil moisture. The Wald statistics showed location (distance to creek and breach) was not or marginally significant, whereas variations between years and elevation were significant

\begin{tabular}{lcccc}
\hline Variable & Parameter & s.e. & Wald statistic & $P$-value \\
\hline Soil-moisture content & Correlation & parameter (exchangeable): 0.376. s.e. 0.074 & \\
Intercept & 68.42 & 6.353 & 116 & $<0.001$ \\
Year 1 & 8.40 & 1.048 & 64.14 & $<0.001$ \\
Year 2 & -1.92 & 1.500 & 1.63 & n.s. \\
Year 3 & 10.35 & 1.145 & 81.75 & $<0.001$ \\
Year 4 & 10.01 & 1.142 & 76.82 & $<0.001$ \\
Year 10 & 16.05 & 0.990 & 262.72 & $<0.001$ \\
Creek far, breach near & 5.94 & 2.175 & 7.47 & $<0.01$ \\
Creek near, breach far & 1.11 & 2.130 & 0.27 & n.s. \\
Creek far, breach far & 3.61 & 1.818 & 3.95 & $<0.05$ \\
Elevation & -0.25 & 0.042 & 36.31 & $<0.001$ \\
Chloride concentration of soil moisture & Correlation parameter (exchangeable): 0.381. s.e. 0.069 & \\
Intercept & 27.948 & 6.907 & 16.37 & $<0.001$ \\
Year 1 & 5.562 & 1.281 & 18.87 & $<0.001$ \\
Year 2 & 14.749 & 2.215 & 44.35 & $<0.001$ \\
Year 3 & 3.609 & 0.843 & 18.35 & $<0.001$ \\
Year 4 & 6.495 & 1.393 & 21.75 & $<0.001$ \\
Year 10 & 6.132 & 1.255 & 23.89 & $<0.001$ \\
Creek far, breach near & 1.871 & 2.148 & 0.76 & n.s. \\
Creek near, breach far & 0.348 & 1.070 & 0.11 & n.s. \\
Creek far, breach far & 0.787 & 1.866 & 0.18 & n.s. \\
Elevation & -0.181 & 0.049 & 13.72 & $<0.001$ \\
\hline Se. & & & &
\end{tabular}

s.e. standard error no significant difference in chloride concentration in soil moisture could be detected between grazed and ungrazed plots in the first 4 years after de-embankment.
It took 10 years before chloride concentrations in soil moisture in the grazed plots were significantly higher than in the ungrazed plots (Fig. 7).
Fig. 3 Comparison between deembanked site $(l e f t)$ and the reference salt marsh (right) over time for two salinity parameters in the top $0-5 \mathrm{~cm}$ soil layer. Soilmoisture content (as weight percentage of dry soil) and chloride concentration in soil moisture were measured over time from 1 year prior to until 10 years after de-embankment. For this comparison, only permanent plots in the grazed deembanked site were included in the analysis. Permanent plots located at an initial elevation lower than $0.5 \mathrm{~m}+$ MHT were assigned to "low marsh," and those higher than $0.5 \mathrm{~m}+$ MHT were assigned to "high marsh"

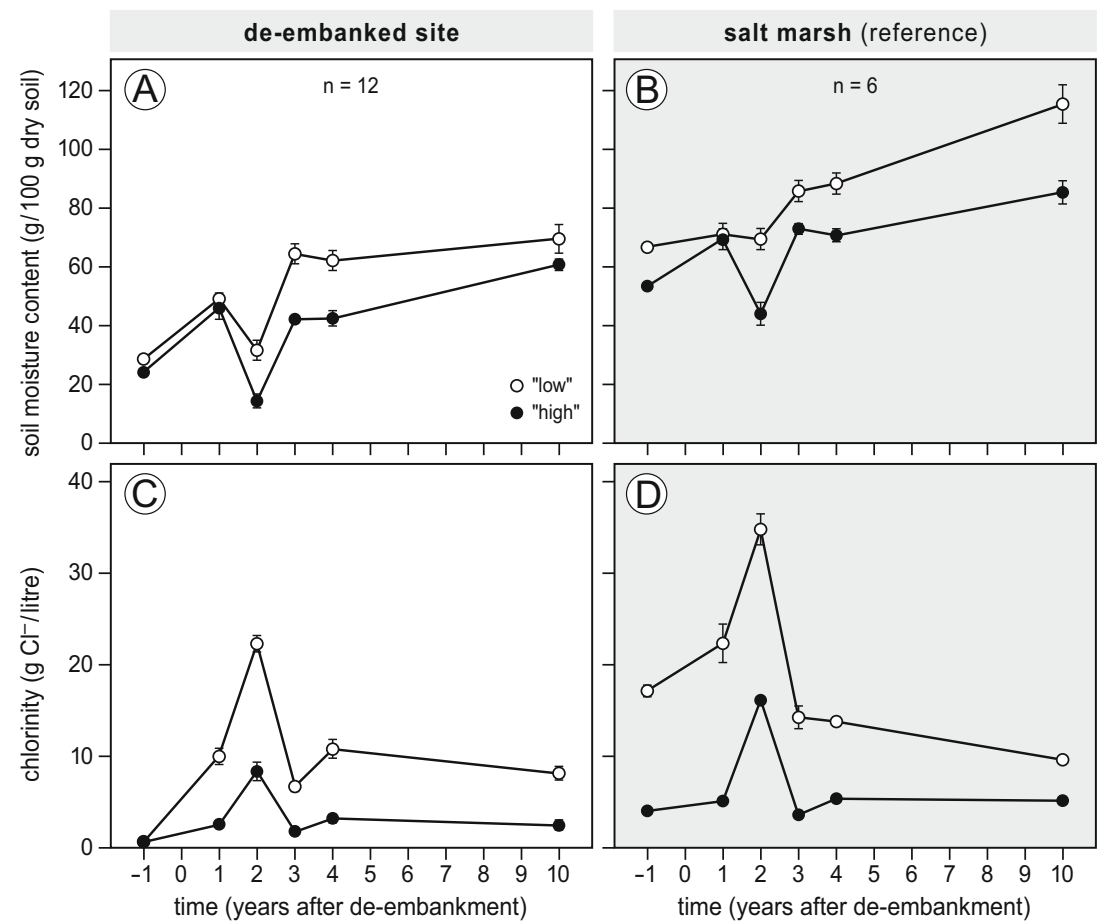


Fig. 4 Comparison of the relation between elevation and the salinity parameters between the de-embanked site and reference site. Figures (a) and (b) represent the relation between elevation and soil moisture content for year 1 and 10 , respectively, and the plots were fitted with an exponential regression line. Figures (c) and (d) represent the relation between elevation and chloride concentration in soil moisture for year 1 and 10, and the plots were also fitted with an exponential regression line
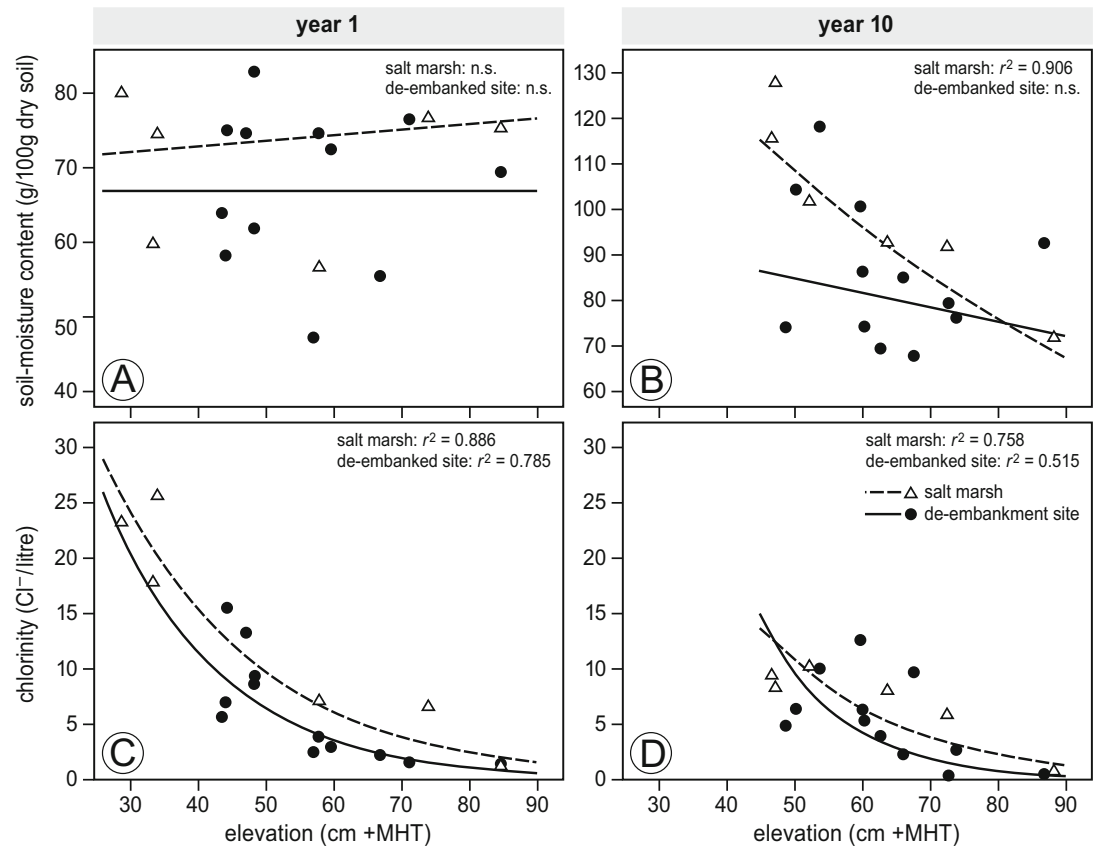

\section{Discussion}

\section{Salinization over time after de-embankment}

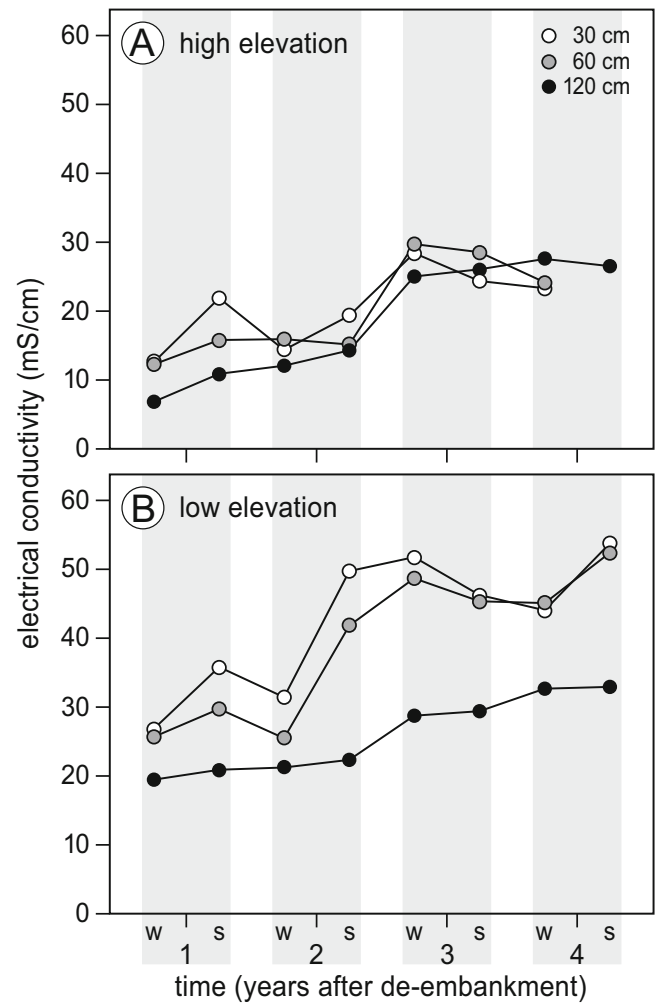

Fig. 5 Increase in the $\mathrm{EC}$ value of the groundwater at three different depths in the de-embanked site during the first 4 years after deembankment at station (a) in the high western part and station (b) in the low eastern part. Data were averaged over a 6-month periods. $\mathrm{w}=$ winter (October - March), s = summer (April - September)
In the first year after de-embankment, chloride concentration of soil moisture showed an immediate response to the reintroduction of the tidal influence on the de-embanked site (Fig. 3d). However, only 10 years after de-embankment did the salinity in the topsoil between the de-embanked sites reach comparable salinity levels to the reference salt marsh at equivalent elevations. Throughout the study period, chloride concentration of the soil moisture fluctuated synchronously with the chloride concentration of soil moisture in the adjacent reference salt marsh. This fluctuating pattern can easily be accounted for by the amount of rainfall or deficit during the days before soil sampling. The high peak of soil-moisture content and low chloride concentration observed in year 3 after de-embankment corresponded strongly with the high rainfall in August of that year. Also in natural salt marshes, salinity of the top soil normally shows high short-term, within-year variations as a result of tidal inundation and, especially, rainfall deficit (Bakker et al. 1985; de Leeuw et al. 1990).

Rapid salinization of the topsoil after de-embankment has also been recorded in some other studies (e.g. MacLeod et al. 1999; Blackwell et al. 2004). However, when greater soil depths are considered, a slower response of salinization to the return of tidal influence may be expected because it depends on the rate of vertical seepage of flood water from the marsh surface into the subsoil (Childers et al. 2000). Based on cores of 0-30 cm in depth, MacLeod et al. (1999) reported a 
Fig. 6 Local differences in salinity parameters in the top 0 $5 \mathrm{~cm}$ of the soil layer related to distance to the creek and the breach 10 years after deembankment $(t=10)$ at the deembanked site. a soil-moisture content and $\mathbf{c}$ chloride concentration in soil moisture. The bars with standard errors represent mean values per sampling station. Different letters show significant differences $(P<0.05)$ between means based on the Tukey test. Figures (b) and (d) represent the relation between elevation and salinity parameters for year 10, fitted with an exponential regression line
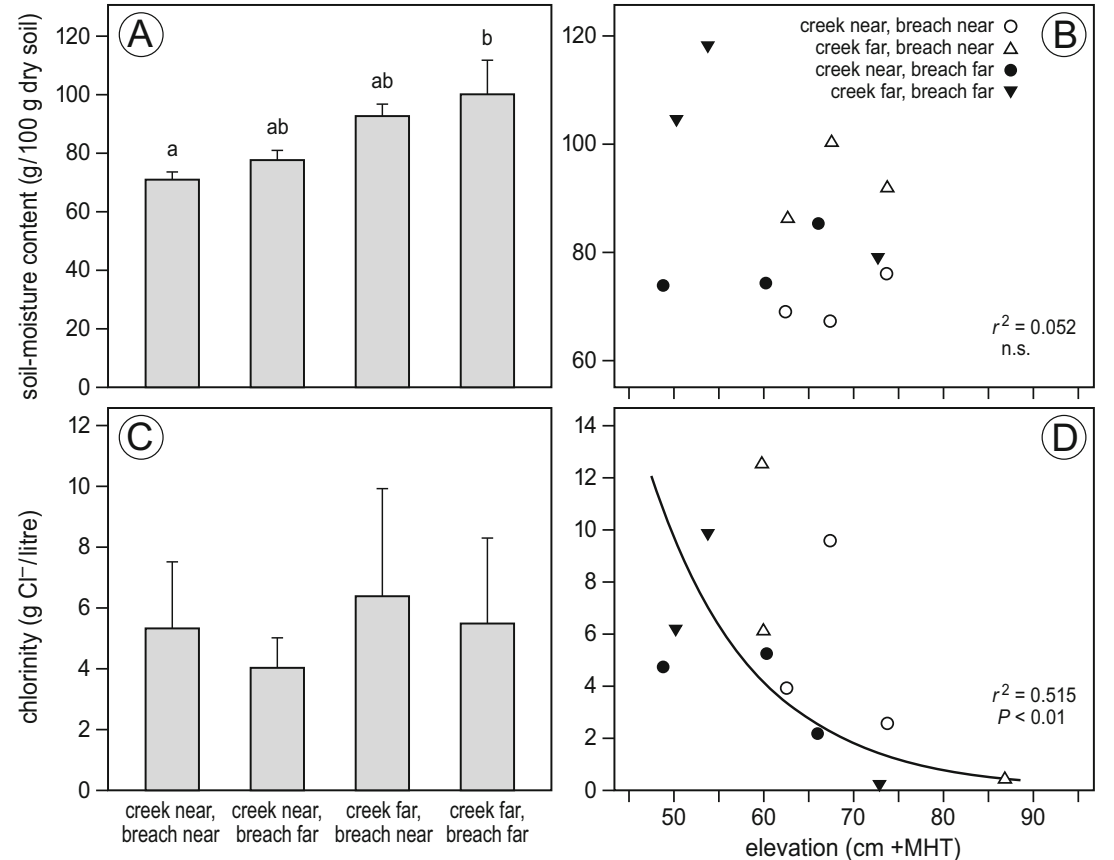

continued increase of marine-associated metal ions in the second year after de-embankment. In our de-embanked site, the increase of the conductivity in the groundwater continued for more than a year at all measuring depths. In particularly, at sampling stations with the lowest elevation, the EC values showed a continued increase into the fourth year after deembankment (Fig. 5).

\section{Salinization and elevation}

A significant negative relation was found between elevation and both soil-moisture content and chloride concentration, though a large variation was found between different years. The strong correlation between elevation and chloride concentration found in this study corresponds with observations both in natural salt marshes (e.g. Callaway et al. 1990; Bockelmann et al. 2002) and de-embanked sites (Davy et al. 2011). A striking observation was the initially lower chloride concentration at the same elevation at the de-embanked site compared to the more seaward-located reference site. There are two possible explanations for this phenomenon. The first is that the chloride concentration of soil moisture in the top soil $(0-5 \mathrm{~cm})$ is influenced by transport from deeper layers by the capillary rise of groundwater during dry spells. Above, we have indicated that after de-embankment, the recharge of salts in the deeper soil layers is a longer-lasting process spanning over several years. This implies that at least during the first years, the supply of salts in the deeper soil for transport to the surface was lower in the de-embanked site than in the reference marsh. It was only in last year
Fig. 7 Effect of grazing on a elevation, b soil-moisture content and $\mathbf{c}$ chloride concentration in soil moisture 10 years after deembankment. Letters indicate significant differences $(P=0.01)$ indicated by a pair-wise $t$-test between grazed and ungrazed locations
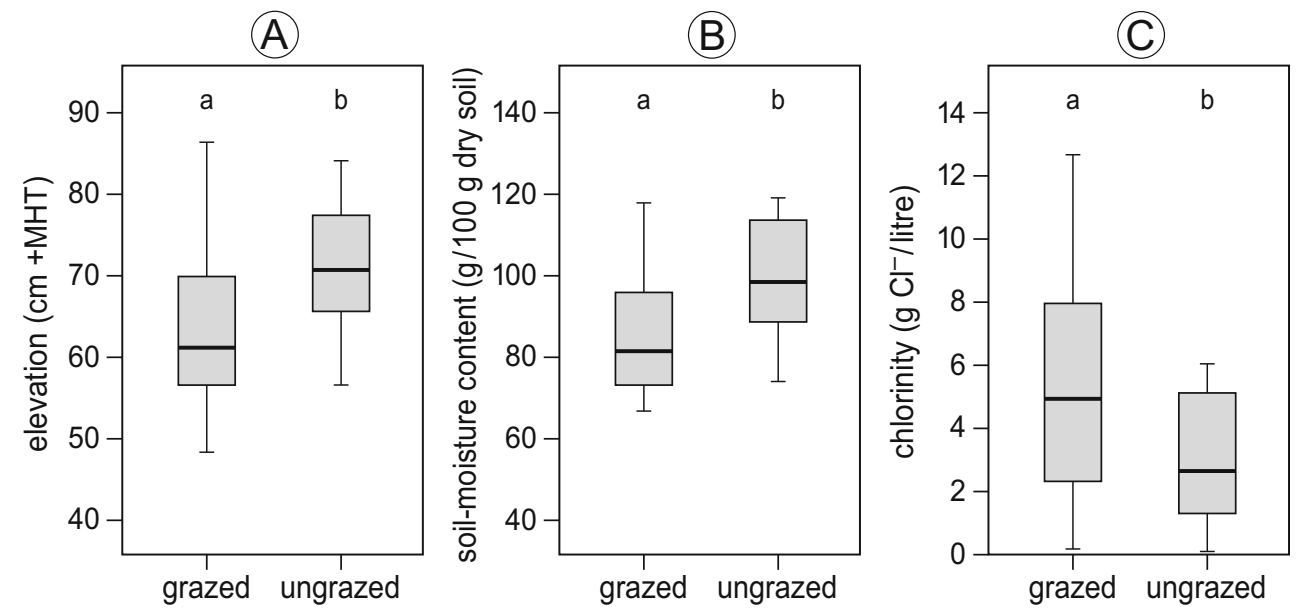
that chloride concentration of soil moisture did not differ significantly anymore between the de-embanked site and reference marsh.

The second explanation is an argument based on a scaledependent process. The reference salt marsh separates the deembanked site from the sea. Now, after they have been merged by the de-embankment, they together form a wider salt marsh. In wide salt marshes, the movement of tidal water entering a salt marsh is distorted by creeks and vegetation, which results in a decrease in the duration of flooding and the level of local MHT (van der Molen 1997). A shallow tidal inundation of the seaward part may occur without affecting the landward part of the marsh at the same or lower elevation. We have no data on actual inundation events in our study area, but the tidal range and the width of our salt marsh are both comparable to the salt marsh studied by van der Molen (1997). In this line of reasoning, not only the total area matters in restoration of coastal salt marshes but also the dimension perpendicular to the coastline. A more diverse salinity gradient may thus develop in a wider marsh compared to the present situation. Currently, with a few exceptions, salt marshes form only a narrow fringe in front of the sea wall as a result of historic land claims. Wide coastal salt marshes also feature a more diverse accretion gradient in comparison with narrow marshes, thus affecting vegetation diversity (Schröder et al. 2002). The more gradient-rich characteristics of wide salt marshes prompted Esselink et al. (2009) to advise for prioritizing the restoration of wide sites in salt-marsh restoration.

\section{Salinization and marsh topography within the de-embanked site}

A slightly but not significantly higher chloride concentration of soil moisture in the top soil at locations near the breach was found, and no relation was found between distance to creek and chloride concentration of soil moisture. This is in contrast to our expectation and other studies. Kim et al. (2010) reported a lower salinity near creeks due to the short period of salt accumulation and higher salinity in inner-marsh areas due to stagnation, evapotranspiration, and resulting high accumulation of salts. Our findings could also be dependent on scale, as Silvestri et al. (2005) showed that only a narrow area near a creek is influenced, in terms of soil aeration, by channel drainage.

Additionally, the study site has a relatively uniform topography. In the UK, areas in which tidal flooding was restored by managed realignment of former salt marshes had been used as agriculturally intensified cropland prior to de-embankment (Brooks et al. 2014). This type of land use before deembankment caused many restored marshes to be topographically more uniform in comparison with the natural state of reference salt marshes (Mossman et al. 2012b; Brooks et al. 2014). Our de-embanked polder had been embanked in 1909 and artificially developed as a salt marsh with a dense drainage grid of ditches $10 \mathrm{~m}$ apart causing a relative uniform topography. Also, the younger seaward reference salt marsh had been artificially developed by enhancement of sedimentary processes like most mainland salt marshes in the Wadden Sea (Dijkema 1997; Esselink et al. 2009). The de-embanked polder was not cultivated with agricultural crops during its 92 years as a summer polder. We, therefore, consider it less likely that the topography was modified by its land-use history. The relatively uniform topography can be primarily accounted for by the developmental history of the site.

\section{Salinization and management}

A large variation in the relation between elevation and both soil moisture content and chloride concentration was observed between different years. As discussed, this variation can be explained by differences in rainfall and inundation frequency. A second possible explanation for the observed variation of the edaphic factors between years could be the grazing regime. Between year 4 and year 10, the grazing regime changed towards more intensive horse grazing at higher stocking densities and an earlier start of the grazing season in part of the study site. The grazing by horses resulted in a change of vegetation composition and greater soil compaction. The comparisons between inside and outside exclosures showed that grazing had significantly negative effects on both accretion and soil-moisture content, and a positive effect on chloride concentration. Ten years after de-embankment, the elevation was significantly higher in the ungrazed plots (on average $+8 \mathrm{~cm}$ ). Higher chloride concentration in grazed than in abandoned areas has also been reported in a natural salt marsh (Bakker et al. 1985). Livestock grazing affects edaphic processes by trampling and defoliation. Trampling by livestock leads to compaction of the soil and, thus, decreased accretion (e.g. Kiehl et al. 2001; Schrama et al. 2013). Several studies have shown that defoliation alters vegetation composition and positively affects soil salinity (e.g. Lavado and Tobada 1987; Teuber et al. 2013; Di Bella et al. 2014). Soil salinity is substantially influenced by the above-ground standing biomass (within the range where biomass is related to total vegetation cover), as vegetation reduces the evaporative water loss from surface sediments, which slows down the upward movement of salts through soil (Srivastava and Jefferies 1996). The positive effect of grazing on establishment of salt-marsh plant communities after de-embankment was also mentioned by Wolters et al. (2005). These authors attributed this positive effect to prevention of dominance by a single tall species in ungrazed, de-embanked sites. Our results also suggest that the higher chloride content of soil moisture resulting from grazing may contribute to the establishment of salt-marsh communities. 


\section{Conclusions}

The de-embankment of agricultural grasslands resulted in a rapid increase of soil salinity, though deeper groundwater showed a much slower response. As we hypothesised, elevation accounted for most of the variation in the salinization of the soil. Five years after de-embankment, the chloride concentrations along the elevation gradient were equivalent to that of the reference salt marsh. Topography (i.e. drainage) had little effect on salinization of the soil. Livestock grazing enhanced evapotranspiration and reduced accretion, thus enhancing the salinization of the soil. Finally, this study has shown that it is essential to conduct a long-term study to evaluate restoration projects as strong year-to-year variation in inundation frequencies and rainfall can result in misinterpretation of trends.

Acknowledgments This study was performed in cooperation with It Fryske Gea. Gerrit van der Leest and Johannes Westerhof checked and maintained the exclosures during our 10-year study. We thank all the people who assisted in the field and made it possible to collect all soil samples in 1 day every year. Nelly Eck processed the soil samples in the laboratory. Albert Ferwerda conducted the EC measurements of the groundwater. Dick Visser prepared the figures, and Esther Chang corrected the English text. This study was performed within the framework of studies that were financially supported by the Waddenfonds, It Fryske Gea, the Prins Bernhard Cultuurfonds, Rijkswaterstaat NoordNederland, the EU Life-Nature Programme, and the Dutch Ministry of Agriculture, Nature and Food Quality.

Open Access This article is distributed under the terms of the Creative Commons Attribution 4.0 International License (http:// creativecommons.org/licenses/by/4.0/), which permits unrestricted use, distribution, and reproduction in any medium, provided you give appropriate credit to the original author(s) and the source, provide a link to the Creative Commons license, and indicate if changes were made.

\section{References}

Adam P (2002) Saltmarshes in a time of change. Environ Conserv 29:39-61

Bakker JP, Dijkstra M, Russchen RT (1985) Dispersal, germination and early establishment of halophytes and glycophytes on a grazed and abandoned salt marsh gradient. New Phytol 101:291-308

Bakker JP, Esselink P, van der Wal R, Dijkema KS (1997) Options for restoration and management of coastal salt marshes in Europe. In: Urbanska KM, Webb NR, Edwards PJ (eds) Restoration ecology and sustainable development. Cambridge University Press, Cambridge, pp. 286-322

Bakker JP, Esselink P, Dijkema KS, van Duin WE, de Jong DJ (2002) Restoration of salt marshes in The Netherlands. Hydrobiologia 478: 29-51

Blackwell MSA, Hogan DV, Maltby E (2004) The short-term impact of managed realignment on soil environmental variables and hydrology. Estuar Coast Shelf Sci 59:687-701

Bockelmann AC, Bakker JP, Neuhaus R, Lage J (2002) The relation between vegetation zonation, elevation and inundation frequency in a Wadden Sea salt marsh. Aquat Bot 73:211-221

Brooks KL, Mossman HL, Chitty JL, Grant A (2014) Limited vegetation development on a created salt marsh associated with over- consolidated sediments and lack of topographic heterogeneity. Estuar Coasts. doi:10.1007/s12237-014-9824-3

Callaway RM, Jones S, Ferren Jr WR, Parikh A (1990) Ecology of mediterranean-climate estuarine wetland at Carpinteria: plant distributions and soil salinity in the upper marsh. Can J Bot 69:11391146

Childers DL, Day JW, McKellar HN (2000) Twenty more years of marsh and estuarine flux studies: revisiting Nixon (1980). In: Weinstein MP, Kreeger DA (eds) Concepts and controversies in tidal marsh ecology. Kluwer Acadamic Publishers, Dordrecht, pp. 391-423

Davy AJ, Brown MJH, Mossman HL, Grant A (2011) Colonization of a newly developing salt marsh: disentangling independent effects of eleveation and redox potential on halophytes. J Ecol 99:1350-1357

de Leeuw J, Olff H, Bakker JP (1990) Year-to-year variation in salt marsh production as related to inundation and rainfall deficit. Aquat Bot 36:139-151

Di Bella CE, Jacobo E, Golluscio RA, Rodríguez AM (2014) Effect of cattle grazing on soil salinity and vegetation composition along an elevation gradient in a temperate coastal salt marsh of Samborombón Bay (Argentina). Wetl Ecol Manag 22:1-13

Dijkema KS (1987) Changes in salt-marsh area in The Netherlands Wadden Sea after 1600. In: Huiskes J, Blom AHL, Rozema CWPM (eds) Vegetation between land and sea. Dr. W. Junk Publishers, Dordrecht, pp. 42-49

Dijkema KS (1997) Impact prognosis for salt marshes from subsidence by gas extraction in the Wadden Sea. J Coast Res 13:1294-1304

Doody JP, Johnston C, Smith B (1993) Directory of the north sea coastal margin. Joint Nature Conservation Committee

Esselink P, Petersen J, Arens S, Bakker JP, Bunje J, Dijkema KS, Hecker N, Hellwig AV, Jensen B, Kers B, Korber P, Lammerts EJ, Luerssen G, Marencic H, Stock M, Veeneklaas RM, Vreeken M, Wolters M. (2009) Salt marshes. Thematic Report No.8. In: Marencic H, de Vlas J (eds) Wadden Sea quality status report 2009. Wadden Sea Ecosystems No. 25. Common Wadden Sea secretariat, Trilateral Monitoring and Assessment Group, Wilhelmshaven, Germany

French PW (2006) Managed realignment - the developing story of a comparatively new approach to soft engineering. Estuar Coast Shelf Sci 67:409-423

Garbutt A, Wolters M (2008) The natural regeneration of salt marsh on formerly reclaimed land. Appl Veg Sci 11:335-344

Gedan KB, Kirwan ML, Wolanski E, Barbier EB, Silliman BR (2011) The present and future role of coastal wetland vegetation in protecting shorelines: answering recent challenges to the paradigm. Clim Chang 106:7-29

Hardin JW, Hibe JM (2003) Generalized estimation equations. Chapman $\&$ Hall/CRC Press, Boca Raton

Hofstee J (1983) Methods of analysis. Part I: soil. Report Ministerie van Verkeer en Waterstaat - Rijksdienst voor IJsselmeerpolders. Lelystad

Hughes R, Fletcher P, Hardy M (2009) Successional development of saltmarsh in two managed realignment areas in SE England, and prospects for saltmarsh restoration. Mar Ecol Prog Ser 384:13-22

Kiehl K, Esselink P, Gettner S, Bakker JP (2001) The impact of sheep grazing on net nitrogen mineralization rate in two temperate salt marshes. Plant Biol 3:553-560

Kim D, Cairns DM, Bartholdy J (2010) Environmental controls on multiscale spatial patterns of salt marsh vegetation. Phys Geogr 31:58-78

Lavado RS, Alconada M (1994) Soil properties behavior on grazed and ungrazed plots of a grassland sodic soil. Soil Technol 7:75-81

Lavado RS, Tobada MA (1987) Soil salinization as an effect of grazing in a native grassland soil in the Flooding Pampa of Argentina. Soil Use Manag 3:143-148

MacLeod CL, Scrimshaw MD, Emmerson RHV, Chang YH, Lester JN (1999) Geochemical changes in metal and nutrient loading at 
Orplands Farm managed retreat site, Essex, UK (April 1995-1997). Mar Pollut Bull 38:1115-1125

Möller I, Kudella M, Rupprecht F, Spencer T, Paul M, van Wesenbeeck BK, Wolters G, Jensen K, Bouma TJ, Miranda-Lange M, Schimmels S (2014) Wave attenuation over coastal salt marshes under storm surge conditions. Nat Geosci 7:727-731. doi:10.1038/ ngeo2251

Mossman HL, Brown MJ, Davy AJ, Grant A (2012a) Constraints on salt marsh development following managed coastal realignment: dispersal limitation or environmental tolerance? Restor Ecol 20:65-75

Mossman HL, Davy AJ, Grant A (2012b) Does managed coastal realignment create saltmarshes with 'equivalent biological characteristics' to natural reference sites? J Appl Ecol 49:1446-1456

Nolte S, Koppenaal EC, Esselink P, Dijkema KS, Schuerch M, de Groot AV, Bakker JP, Temmerman S (2013) Measuring sedimentation in tidal marshes: a review on methods and their applicability in biogeomorphological studies. J Coast Conserv 17:301-325

Pétillon J, Erfanzadeh R, Garbutt A, Maelfait JP, Hoffmann M (2010) Inundation frequency determines the post-pioneer successional pathway in a newly created salt marsh. Wetlands: 30:1097-1105

Schrama M, Heijning P, Bakker JP, van Wijnen HJ, Berg M, Olff H (2013) Herbivore trampling as an alternative pathway for explaining differences in nitrogen mineralization in moist grassslands. Oecologia 172:231-243

Schröder HK, Kiehl K, Stock M (2002) Directional and non-directional vegetation changes in a temperate salt marsh in relation to biotic and abiotic factors. Appl Veg Sci 5:22-44

Schroor M (2009) Van Keeg tot Leeg: Geschiedenis van het Noorderleegs-Buitenveld. It Fryske Gea. Olterterp

Silvestri S, Defina A, Marani M (2005) Tidal regime, salinity and salt marsh plant zonation. Estuar Coast Shelf Sci 62:119-130
Srivastava DS, Jefferies RL (1996) A postitieve feedback: herbivory, plant growth, salinity, and the desertification of an Arctic salt-marsh. J Ecol 84:31-42

Suchrow S, Pohlman M, Stock M, Jensen K (2012) Long-term surface elevation change in German North Sea salt marshes. Estuar Coast Shelf Sci 98:75-83

TEEBcase (2011) Managed realignment for coastal protection, UK. Compiled by J. Förster and L. De Muelenaere mainly based on Turner et al. 2007 and DEFRA and EA 2002. Available at: TEEBweb.org

Teuber LM, Hölzel N, Fraser LH (2013) Livestock grazing in intermountain depressional wetlands - effects on plant strategies, soil chracteristics and biomass. Agric Ecosyst Environ 175:21-28

van der Molen J (1997) Tidal distortion and spatial differences in surface flooding characteristics in a salt marsh: implications for sea-level reconstruction. Estuar Coast Shelf Sci 45:221-233

Veeneklaas RM (2013) Adaptation and dispersal of the native invasive salt marsh species Elytrigia atherica. $\mathrm{PhD}$ Thesis, University of Groningen, Groningen

Westhoff V, Hobohm C, Schaminée JHJ (1993) Rote Liste der Pflanzengesellschaften des Naturraumes Wattenmeer unter Berücksichtigung der ungefährdeten Vegetationseinheiten. Tuexenia 13:109-140

Wolters M, Garbutt A, Bakker JP (2005) Salt-marsh restoration: evaluating the success of de-embankments in North-West Europe. Biol Conserv 123:249-268

Wolters M, Garbutt A, Bekker RM, Bakker JP, Carey PD (2008) Restoration of salt-marsh vegetation in relation to site suitability, species pool and dispersal traits. J Appl Ecol 45:904-912

Zedler JB, Callaway JC, Desmond JS, Vivian SG, Williams GD, Sullivan G, Brewster AE, Bradshaw BK (1999) Californian salt-marsh vegetation: an improved model of spatial pattern. Ecosystems 2:19-35 